\title{
PERAN KEMAMPUAN AWAL MATEMATIKA DAN PERSEPSI MAHASISWA PADA STATISTIKA TERHADAP PRESTASI BELAJAR STATISTIKA
}

\author{
Purni Munah Hartuti ${ }^{1}$, Halleyna Widyasari ${ }^{2}$ \\ Program Studi Teknik Informatika, Universitas Indraprasta PGRI ${ }^{1}$ \\ Email: purniibunyahanum@yahoo.co.id ${ }^{1}$ \\ Program Studi Teknik Informatika, Universitas Indraprasta PGRI ${ }^{2}$ \\ Email: halleynawidyasari0@gmail.com²
}

\begin{abstract}
Abstrak
Sering dijumpai mahasiswa yang mengambil jurusan Teknik Informatika tidak menduga akan mendapatkan mata kuliah matematika. Mahasiswa menganggap bahwa mengambil program studi Teknik Informatika hanya akan mendapatkan mata kuliah pemrograman saja. Namun pada kenyataannnya, mata kuliah matematika di program studi Teknik Informatika kira-kira sebesar 30\%. Banyak mahasiswa yang menganggap remeh mata kuliah matematika dan kurang memahami bahwa belajar matematika sangat penting dalam mempelajari program. Permasalahan yang akan diteliti adalah peran kemampuan awal matematika dan persepsi mahasiswa terhadap prestasi belajar statistika. Tujuan penelitian ini adalah untuk mengetahui seberapa besar pengaruh kemampuan awal matematika dan persepsi mahasiswa terhadap prestasi belajar statistika. Metode penelitian adalah metode survey dengan instrumennya berupa angket. Data dianalisis dengan analisis regresi menggunakan software SPSS Statistic 17.0. Berdasarkan hasil analisis dan pembahasan dapat diambil kesimpulan di antaranya: 1) kemampuan awal memberikan pengaruh terhadap prestasi belajar yang tidak signifikan, 2) persepsi pada mata kuliah statistika memberikan pengaruh terhadap prestasi belajar yang signifikan, 3) kemampuan awal dan persepsi memberikan pengaruh secara bersama-sama terhadap prestasi belajar. Dengan melihat kemampuan awal yang tidak signifikan, dosen diharapkan memberikan motivasi kepada mahasiswa untuk lebih giat belajar latihan soal agar prestasi belajar meningkat. Mahasiswa dengan persepsi tinggi terhadap mata kuliah statistika diharapkan memberikan motivasi kepada mahasiswa lain.
\end{abstract}

Kata Kunci: Kemampuan Awal Matematika, Persepsi Mahasiswa, Prestasi Belajar Statistika

\section{Pendahuluan}

Dalam kehidupan sehari-hari, sering kita jumpai informasi-informasi statistika yang disajikan melalui media, baik cetak maupun elektronik. Informasi-informasi tersebut tersaji dalam bentuk angka, tabel, maupun grafis. Informasi jumlah penduduk, presentase pertumbuhan ekonomi, hasil pooling pemilihan umum, dan lain sebagainya merupakan contoh yang berkaitan dengan pemanfaatan statistika. Pemahaman terhadap statistika menjadi sangat penting dalam kehidupan manusia.

Mata kuliah statistika adalah salah satu mata kuliah yang diajarkan di perguruan tinggi. Diharapkan dengan mata kuliah ini, mahasiswa dapat menggali informasi yang bersifat kuantitatif. Mahasiswa diharapkan memiliki kemampuan dalam menggunakan pendekatan ilmiah, misalnya: dalam penulisan skripsi untuk memecahkan suatu permasalahan. Dalam memecahkan masalah, statistika berperan sebagai alat bantu untuk menangani data-data kuantitatif yang diperoleh dari penelitian. Dengan demikian, melalui analisis statistik akan diperoleh gambaran situsi, kondisi atau fakta yang sekaligus memberikan kesimpulan yang masuk akal.

Sedemikan pentingnya statistika, namun umumnya mahasiswa kurang berminat mempelajarinya. Adanya persepsi bahwa mempelajari statistika membutuhkan kemampuan matematika menjadi salah satu sebabnya. Statistika dan matematika memiliki persamaan dalam menggunakan prinsip-prinsip aritmatika. Perbedaan yang mendasar antara lain 
matematika berkaitan dengan sesuatu yang pasti, presisi, eksakta, dan tepat sementara statistika berurusan dengan sesuatu yang tidak pasti, yang penekanannya pada penalaran dan pembuatan keputusan.

Universitas Indraprasta PGRI memberikan mata kuliah statistika dasar kepada seluruh mahasiswa semester III program studi Teknik Informatika sebagai mata kuliah wajib. Sifat mahasiswa yang heterogen dari latar belakang pendidikan, diduga menjadi penyebab perbedaan prestasi belajar statistika selama ini. Mahasiswa dari latar belakang pendidikan IPA berbeda dengan yang berlatar belakang IPS dalam hal pemahaman aritmatika matematika yang berkaitan dengan statistika. Namun demikian, juga terdapat persepsi individual yang berbeda terhadap penggunaan matematika dalam mempelajari statistika.

Dari berbagai faktor penyebab rendahnya prestasi belajar statistika tersebut, penulis berkecenderungan menyimpulkan bahwa faktor yang menyebabkan rendahnya mutu pembelajaran statistika disebabkan karena kurangnya kemampuan awal matematika dan persepsi mahasiswa pada mata kuliah statistika.

\section{Tinjauan Pustaka \\ Prestasi Belajar Statistika}

Slameto (2010) menyatakan, "belajar adalah suatu proses usaha yang dilakukan seseorang untuk memperoleh suatu perubahan tingkah laku yang baru secara keseluruhan, sebagai hasil pengalamannya sendiri dalam interaksi dengan lingkungannya". Usaha seseorang dalam mencapai sesuatu hal berkaitan dengan usahanya untuk belajar, dengan belajar maka seseorang memperoleh perubahan tingkah laku. Belajar bukan berarti membaca buku pelajaran tetapi belajar yang dimaksud di sini yaitu dari pengalaman kita bisa belajar dari kegagalan.

Tirtarahardja (dalam Astuti\&Leonard, 2012), "belajar adalah perubahan perilaku yang relatif tetap karena pengaruh pengalaman". Menurut pengertian ini, belajar adalah suatu proses kegiatan dan bukan hasil atau tujuan. Belajar tidak hanya mengingat, akan tetapi lebih luas daripada itu, yakni mengalami. Lebih jauh Musfiqon (dalam Astuti\&Leonard, 2012) berpendapat bahwa "belajar dapat didefinisikan sebuah proses interaksi antara manusia dengan lingkungan yang dilakukan secara terencana untuk mencapai pemahaman, keterampilan, dan sikap yang diinginkan sehingga terjadi perubahan pada diri seseorang dari prestasi belajar tersebut, yaitu kedewasaan diri”. Belajar merupakan aktivitas terencana untuk mendapatkan pengetahuan dan wawasan, agar perilaku seseorang berubah menuju pada kedewasaan. Pemahaman yang telah didapat menjadi sumber nilai yang mempengaruhi seseorang dalam berpikir, bertindak, dan berperilaku.

Belajar merupakan suatu proses internal yang kompleks, belajar merupakan proses internal peserta didik yang tidak dapat diamati secara langsung oleh guru, tetapi dapat dipahami oleh guru melalui perilaku peserta didik yang mempelajari bahan belajar. Menurut Arifin (dalam Astuti\&Leonard, 2012) bahwa "prestasi belajar merupakan suatu masalah yang bersifat perennial dalam sejarah kehidupan manusia, karena sepanjang rentang kehidupannya manusia selalu mengejar prestasi menurut bidang dan kemampuan masing-masing". Dari teori di atas, maka pengertian prestasi belajar itu adalah ilmu pengetahuan yang diperoleh dalam proses belajar yang dihasilkan dari tes beberapa bidang studi sehingga mendapatkan hasil/skor.

Purwadarminto (dalam Nirmalawati, 2010) rnenyatakan bahwa prestasi belajar adalah hasil yang dicapai sebaik-baiknya menurut kemampuan anak pada waktu tertentu terhadap hal-hal yang dikerjakan atau dilakukan. Jadi, prestasi belajar adalah hasil belajar yang telah dicapai menurut kemampuan yang tidak dimiliki dan ditandai dengan perkembangan serta perubahan 
tingkah laku pada diri seseorang yang diperlukan dari belajar dengan waktu tertentu, prestasi belajar ini dapat dinyatakan dalam bentuk nilai dan hasil tes atau ujian. Winkel (dalam Nirmalawati, 2010) mengemukakan bahwa prestasi belajar merupakan bukti keberhasilan yang telah dicapai oleh seseorang. Jadi, prestasi belajar merupakan hasil maksimum yang dicapai oleh seseorang setelah melaksanakan usaha-usaha belajar. Lebih lanjut, Arif Gunarso (dalam Nirmalawati, 2010) mengemukakan bahwa prestasi belajar adalah usaha maksimal yang dicapai oleh seseorang setelah melaksanakan usaha-usaha belajar. Berdasarkan pendapat dari beberapa ahli pendidikan, maka pengertian prestasi belajar menurut penulis adalah hasil maksimal dari pengukuran terhadap peserta didik yang meliputi faktor kognitif, afektif dan psikomotor setelah mengikuti proses pembelajaran yang diukur dengan menggunakan instrumen tes yang relevan.

Betapa pentingnya seorang pengajar mengetahui dan memahami prestasi belajar peserta didik, baik secara perseorangan maupun secara kelompok, sebab fungsi prestasi belajar tidak hanya sebagai indikator keberhasilan dalam bidang studi tertentu, tetapi juga sebagai indikator kualitas institusi pendidikan. Arifin (dalam Astuti\&Leonard, 2012) berpendapat lain bahwa "prestasi belajar juga bermanfaat sebagai umpan balik bagi guru dalam melaksanakan proses pembelajaran sehingga dapat menentukan apakah perlu melakukan diagnosis, penempatan, atau bimbingan terhadap peserta didik". Hasil penilaian dari evaluasi merupakan umpan balik untuk mengukur sampai dimana keberhasilan proses belajar mengajar. Dengan nilai-nilai yang diperoleh peserta didik, guru pun akan mengetahui sejauh mana keberhasilannya dalam mengajar, dan hal itu dapat digunakan untuk perbaikan dalam proses pembelajaran berikutnya.

Sudjana (dalam Supardi, 2013) mendefinisikan statistika sebagai pengetahuan yang berhubungan dengan cara-cara mengumpulkan data, pengolahan atau penganalisaannya dan penarikan kesimpulan berdasarkan kumpulan data dan penganalisisan yang telah dilakukan. Statistika dapat diartikan sebagai ilmu pengetahuan yang mempelajari tentang bagaimana cara kita mengumpulkan, mengolah, menganalisis dan menginterpretasikan data sehingga dapat disajikan dengan lebih baik dan dapat ditarik kesimpulan. Statistika adalah sekumpulan fakta yang berbentuk angka-angka yang disusun dalam bentuk daftar atau tabel. Statistik adalah perhitungan atau rumus-rumus yang digunakan dalam pengolahan data tersebut. Atau dapat diartikan sebagai sekumpulan data kuantitatif yang tersaji dalam bentuk tabel, grafik, simbol, atau ukuran-ukuran.

Peneliti menyimpulkan bahwa prestasi belajar statistika adalah merupakan suatu tingkat pencapaian perubahan pengetahuan, sikap, kecakapan, atau perilaku akademik yang dinilai oleh guru dengan tes yang hasilnya diwujudkan dalam suatu simbol yang biasanya dipergunakan adalah berupa angka 0-10 atau angka 0-100 atau huruf A, B, C, D, E, dimana yang dipelajari adalah pengetahuan yang berhubungan dengan pengumpulan data, pengolahan data, penyajian data, penganalisaan data, serta penarikan kesimpulan dan pengambilan keputusan secara logis dan rasional tentang data tersebut.

\section{Kemampuan Awal Matematika}

Matematika merupakan ilmu universal yang mendasari perkembangan teknologi modern. Matematika mempunyai peran penting dalam mengembangkan daya pikir manusia. Perkembangan di bidang teknologi informasi dan komunikasi dilandasi oleh perkembangan matematika. Peran teori bilangan, aljabar, aljabar analitik, teori peluang dan matematika diskrit sangat signifikan terhadap perubahan peradaban manusia. Mengingat besarnya peran matematika terhadap kehidupan manusia, hampir setiap negara berusaha membangun sistem pendidikan dan menempatkan pembelajaran matematika sebagai salah satu materi pokok. Hal tersebut didukung oleh asumsi bahwa, langkah utama untuk dapat membangun dapat 
menguasai dan menciptakan teknologi di masa depan diperlukan penguasaan matematika yang kuat.

Matematika merupakan landasan pokok ilmu-ilmu pengetahuan lain, hal ini dimungkinkan karena matematika dibangun secara ilmiah dan lebih mengedepankan berpikir logis, praktis dan ilmiah. Keberadaan matematika tidak hanya bermanfaat bagi dirinya sendiri namun bermanfaat bagi perkembangan ilmu-ilmu lain, baik eksak maupun ilmu-ilmu sosial. Melalui matematika akan memungkinkan seseorang untuk berpikir dan menganalisa suatu masalah tanpa batas dan memiliki kebebasan dalam mengembangkan berbagai ideide brilian demi mencari kebenaran.

Russefendi, E.T (dalam Liberna, 2009) mengemukakan bahwa matematika merupakan suatu ilmu yang berpengaruh dengan penelaahan bentuk-bentuk atau struktur-struktur yang abstrak dan berpengaruh di antara hal itu. Untuk dapat memahami struktur-struktur serta pengaruh-pengaruhnya diperlukan pemahaman tentang konsep-konsep yang terdapat di dalam matematika.

Kemampuan awal berasal dari kata mampu yang berarti kuasa (bisa sanggup) melakukan sesuatu, dapat. Kemudian mendapat imbuhan ke-an menjadi kemampuan yang berarti kesanggupan, kecakapan, kekuatan.

Kemampuan awal peserta didik adalah kemampuan yang telah dimiliki oleh peserta didik sebelum ia mengikuti pelajaran yang akan dberikan. Kemampuan awal menggambarkan kesiapan peserta didik dalam menerima pelajaran yang akan disampaikan. Kemampuan awal peserta didik perlu untuk diketahui dosen sebelum memulai pembelajaran karena dengan demikian dapat diketahui apakah peserta didik telah mempunyai pengetahuan awal yang merupakan prasyarat untuk mengikuti pembelajaran. Sejauh mana peserta didik mengetahui materi apa yang akan disajikan. Kemampuan awal peserta didik dapat diukur melalui tes awal, interview atau cara-cara lain yang cukup sederhana seperti melontarkan pertanyaanpertanyaan secara acak dengan distribusi perwakilan peserta didik.

Menurut Nur (dalam Trianto, 2007) menjelaskan kemampuan awal adalah sekumpulan pengetahuan dan pengalaman individu yang diperoleh sepanjang perjalanan hidup mereka, dan apa yang ia bawa kepada suatu pengalaman belajar baru.

Menurut Sutrisno (1993) kemampuan awal adalah pengetahuan alam dan ketrampilan yang relavan termasuk di dalamnya lain-lain latar belakang informasi karakteristik peserta didik yang telah ia miliki pada saat akan memulai mengikuti suatu program pengajaran.

Dari uraian d iatas, dapat diambil kesimpulan bahwa kemampuan awal merupakan bekal pengetahuan yang sesuai yang dimiliki peserta didik dengan memahami konsep awal dengan baik dan mendalam, maka peserta didik tidak akan mengalami kesulitan yang berarti untuk mempelajari dan menguasai serta memahami materi pelajaran selanjutnya.

\section{Persepsi Mahasiswa pada Mata Kuliah Statistika}

Menurut Drever (dalam Adi, 2010), persepsi adalah suatu proses pengenalan atau identifikasi sesuatu dengan menggunakan panca indera. Kesan yang diterima individu sangat tergantung pada seluruh pengalaman yang telah diperoleh melalui proses berpikir dan belajar, serta dipengaruhi oleh faktor yang berasal dari dalam diri individu. Sabri (dalam Adi, 2010) mendefinisikan persepsi sebagai aktivitas yang memungkinkan manusia mengendalikan rangsangan-rangsangan yang sampai kepadanya melalui alat inderanya, menjadikannya kemampuan itulah dimungkinkan individu mengenali milleu (lingkungan pergaulan) 
hidupnya. Proses persepsi terdiri dari tiga tahap yaitu tahapan pertama terjadi pada pengideraan diorganisir berdasarkan prinsip-prinsip tertentu, tahapan ketiga yaitu stimulasi pada penginderaan diinterprestasikan dan dievaluasi. Mar'at (dalam Adi, 2010) mengatakan bahwa persepsi adalah suatu proses pengamatan seseorang yang berasal dari suatu kognisi secara terus menerus dan dipengaruhi oleh informasi baru dari lingkungannya.

Menurut Desmita (2010), persepsi adalah suatu proses penggunaan pengetahuan yang telah dimiliki untuk memperoleh dan menginterpretasi stimulus (rangsangan) yang diterima oleh sistem alat indra manusia. Jadi persepsi pada dasarnya menyangkut hubungan manusia dengan lingkungannya, bagaimana ia mengerti dan menginterpretasikan stimulus yang ada di lingkungannya dengan menggunakan pengetahuan yang dimilikinya. Setelah individu menginderakan objek di lingkungannya, kemudian ia memproses hasil penginderaannya itu, sehingga timbullah makna tentang objek itu.

Persepsi merupakan suatu proses tentang petunjuk-petunjuk indrawi/sensori dan pengalaman masa lampau yang relevan diorganisasikan untuk memberikan gambaran yang terstruktur dan bermakna pada situasi tertentu. Persepsi bertautan dengan cara menapatkan pengetahuan khusus tentang kejadian pada saat tertentu, maka persepsi dapat terjadi kapan saja apabila ada stimulus yang menggerakkan indera. Dalam hal ini, persepsi diartikan sebagai proses mengetahui atau mengenali objek dan kejadian objek dengan bantuan indera. (Chaplin, CP, 1999)

Menurut Suharnan (2005) bahwa persepsi merupakan tahap paling awal dari serangkaian pemrosesan informasi. Persepsi adalah suatu proses penggunaan pengetahuan yang telah dimiliki (yang disimpan dalam ingatan) untuk mendeteksi atau memperoleh dan menginterpretasi stimulus (rangsangan) yang diterima oleh alat indera manusia. Berdasarkan pemahaman tersebut, persepsi merupakan proses menginterpretasikan atau menafsirkan informasi yang diperoleh melalui sistem alat indera manusia, yang mencakup dua proses yang berlangsung secara serempak antara keterlibatan aspek-aspek dunia luar (stimulusinformasi/pengalaman) dengan dunia di dalam diri seseorang (pengetahuan yang relevan dan telah disimpan dalam ingatan).

Persepsi pada hakikatnya adalah merupakan aktivitas mengindera, mengintegrasikan dan memberikan penilaian pada objek-objek fisik maupun objek sosial, dan penginderaan tersebut tergantung pada stimulus fisik dan stimulus sosial yang ada di lingkungannya. Sensasi-sensasi dari lingkungan akan diolah bersama-sama dengan hal-hal yang telah dipelajari sebelumnya, baik berupa harapan-harapan, nilai-nilai, sikap, ingatan dan lain-lain. Di dalam proses persepsi individu dituntut untuk memberikan penilaian terhadap suatu objek yang dapat bersifat positif atau negatif, senang atau tidak senang dan sebagainya. Dengan adanya persepsi maka akan terbentuk sikap, yaitu suatu kecenderungan yang stabil untuk berlaku atau bertindak secara tertentu di dalam situasi yang tertentu pula. Dengan demikian, persepsi merupakan suatu fungsi biologis (melalui organ-organ sensoris) dan sekaligus fungsi psikologis yang memungkinkan individu menerima dan mengolah informasi dari lingkungan dan mengadakan perubahan-perubahan di lingkungannya. Lebih lanjut, persepsi adalah suatu proses aktivitas seseorang dalam memberikan kesan, penilaian, pendapat, merasakan dan menginterpretasikan sesuatu berdasarkan informasi yang ditampilkan dari sumber lain (yang dipersepsi). Melalui persepsi kita dapat mengenali dunia sekitar kita, yaitu seluruh dunia yang terdiri dari benda serta manusia dengan segala kejadian-kejadiannya. Dengan persepsi pula kita dapat berinteraksi dengan dunia sekeliling kita, khususnya antar manusia.

Berdasarkan beberapa pengertian di atas, disimpulkan bahwa persepsi adalah suatu proses yang kompleks dimana individu menerima dan menyadap informasi dari lingkungan, 
mengintegrasikan atau mengorganisasikan dan menginterpretasikan suatu objek, dengan adanya keterlibatan aspek-aspek dunia luar (stimulus-informasi/pengalaman) dengan dunia di dalam diri seseorang (pengetahuan yang relevan dan telah disimpan dalam ingatan), sehingga mampu memahami objek yang ada di hadapan kita.

Persepsi mahasiswa pada mata kuliah statistika adalah suatu proses mahasiswa mengenali mata kuliah statistika. Ada mahasiswa yang mengenali dengan sikap positif yaitu menganggap mudah ada pula yang mengenali dengan sikap negatif yaitu menganggap sukar. Mahasiswa yang menyenangi mata kuliah statistika cenderung akan giat dan ikhlas mempelajari, sedangkan mahasiswa yang tidak menyenangi tentu saja akan malas-malasan untuk mempelajarinya. Hal tersebut tentu saja mempengaruhi prestasi belajar mata kuliah ststistika mahasiswa tersebut.

\section{Metodologi Penelitian}

Metode Penelitian ini menggunakan metode survei. Responden atau sampel diambil dari mahasiswa Universitas Indraprasta PGRI semester III yag diambil secara acak sebanyak 40 mahasiswa. Jenis data yang digunakan dalam penelitian ini adalah berupa data instrumen tes kemampuan awal dan instrumen persepsi mahasiswa pada mata kuliah statistika. Setelah instrumen tersebut dilakukan analisis validitas dan reliabilitasnya. Untuk memberi gambaran, maka desain penelitian ditunjukkan melalui gambar sebagai berikut:

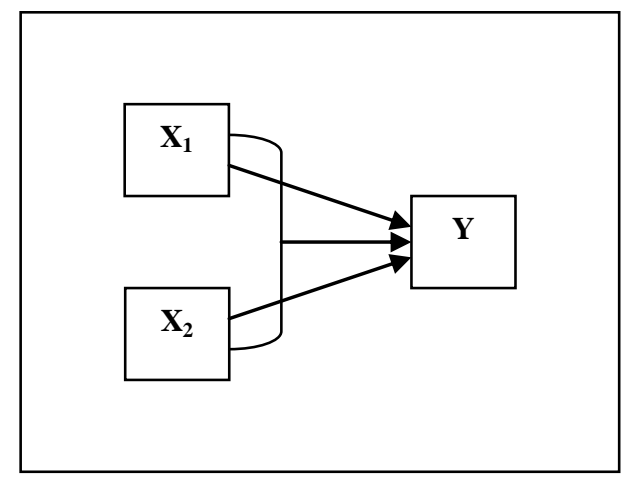

Gambar 1. Desain Penelitian

Keterangan:

$\mathrm{X}_{1} \quad$ : kemampuan awal matematika

$\mathrm{X}_{2} \quad$ : persepsi mahasiswa pada mata kuliah statistika

Y : prestasi belajar statistika

Analisis data menggunakan teknik analisis deskriprif untuk mencari harga rata-rata, simpangan baku, distribusi frekuensi, modus, mean, median. Uji persyaratan analisis data yang digunakan adalah uji Normalitas dan uji Linieritas. Teknik pengujian hipotesis yang digunakan adalah analisis korelasi dan regresi ganda.

\section{Hasil dan Pembahasan \\ Hasil Penelitian}

Data diperoleh dari hasil pengukuran prestasi belajar statistika, hasil skor perhitungan tes kemampuan awal matematika dan hasil skor perhitungan angket persepsi mahasiswa sebagai berikut: 
Tabel 1. Hasil Rangkuman Statistik Deskriptif

\begin{tabular}{lccccc}
\hline \hline & N & Min & Max & Mean & Std. Deviation \\
\hline Prestasi_Belajar_Statistika & 40 & 56.00 & 99.00 & 71.900 & 12.22926 \\
Kemampuan_Awal_Matematika & 40 & 40.00 & 93.00 & 70.000 & 13.26649 \\
Persepsi_Mahasiswa & 40 & 36.00 & 92.00 & 69.2500 & 15.79638 \\
Valid N (listwise) & 40 & & & & \\
\hline
\end{tabular}

Untuk mengetahui peran kemampuan awal dan persepsi mahasiswa pada mata kuliah statistika terhadap prestasi belajar mata kuliah statistika, peneliti menggunakan analisis regresi ganda dengan memanfaatkan program SPSS 17.

Analisis uji korelasi peran kemampuan awal matematika dan persepsi mahasiswa pada mata kuliah statistika terhadap prestasi belajar mata kuliah statistika disajikan dalam tabel berikut.

\section{Tabel 2. Analisis Korelasi Peran Kemampuan Awal Matematika dan Persepsi Mahasiswa pada Mata Kuliah Statistika terhadap Prestasi Belajar} Mata Kuliah Statistika

\begin{tabular}{llccc}
\hline Model & R & R Square & Adjusted R Square & Std. Error of the Estimate \\
\hline 1 & $.680^{\mathrm{a}}$ & 0.463 & 0.434 & 9.20029 \\
\hline
\end{tabular}

$\mathrm{H}_{0}: \rho_{\mathrm{y} 12}=0$, artinya tidak ada hubungan kemampuan awal matematika dan persepsi mahasiswa pada mata kuliah statistika terhadap prestasi belajar mata kuliah statistika.

$\mathrm{H}_{1}: \rho_{\mathrm{y} 12} \neq 0$ artinya ada hubungan kemampuan awal matematika dan persepsi mahasiswa pada mata kuliah statistika terhadap prestasi belajar mata kuliah statistika.

Bahwa koefisien korelasi $\left(r_{\mathrm{y} 12}\right)$ sebesar 0,680 lebih besar dari $\mathrm{r}_{\text {tabel }} 0,312$ mempunyai makna bahwa hubungan kemampuan awal matematika dan persepsi mahasiswa pada mata kuliah statistika terhadap prestasi belajar mata kuliah statistika adalah kuat. Sementara koefisien determinasi $\left(\mathrm{r}_{\mathrm{y} 12}^{2}\right)$ sebesar 0,463 mempunyai makna bahwa kemampuan awal matematika dan persepsi mahasiswa pada mata kuliah statistika terhadap prestasi belajar mata kuliah statistika memberikan kontribusi sebesar 46,3\% sedangkan selebihnya dipengaruhi oleh faktor lain.

Analisis uji signifikansi hubungan kemampuan awal matematika dan persepsi mahasiswa pada mata kuliah statistika terhadap prestasi belajar mata kuliah statistika disajikan dalam tabel berikut.

\section{Tabel 3. Analisis Uji Signifikansi Peran Kemampuan Awal Matematika dan Persepsi Mahasiswa pada Mata Kuliah Statistika terhadap Prestasi Belajar} Mata Kuliah Statistika

\begin{tabular}{llrrrrr}
\hline Model & & Sum of Squares & df & Mean Square & F & Sig. \\
\hline 1 & Regression & 2700.764 & 2 & 1350.382 & $\mathbf{1 5 . 9 5 3}$ & $.000^{\mathrm{a}}$ \\
& Residual & 3131.876 & 37 & 84.645 & & \\
& Total & 5832.64 & 39 & & & \\
\hline
\end{tabular}

Hipotesis yang diuji:

$\mathrm{H}_{0}: \beta_{1}=\beta_{2}=0$, artinya tidak terdapat pengaruh yang signifikan antara kemampuan awal matematika dan persepsi mahasiswa pada mata kuliah statistika terhadap prestasi belajar mata kuliah statistika. 
$\mathrm{H}_{1}$ : bukan $\mathrm{H}_{0}$, artinya terdapat pengaruh yang signifikan antara kemampuan awal matematika dan persepsi mahasiswa pada mata kuliah statistika terhadap prestasi belajar mata kuliah statistika.

Kriteria pengujian:

$\mathrm{F}_{\text {hitung }}>\mathrm{F}_{\text {tabel }}, \mathrm{H}_{0}$ ditolak $\mathrm{H}_{1}$ diterima.

$\mathrm{F}_{\text {hitung }}<\mathrm{F}_{\text {tabel }}, \mathrm{H}_{0}$ diterima $\mathrm{H}_{1}$ ditolak.

15,953>3,25 $\mathrm{H}_{0}$ ditolak $\mathrm{H}_{1}$ diterima berarti terdapat pengaruh positif dan signifikan antara kemampuan awal matematika dan persepsi mahasiswa pada mata kuliah statistik terhadap prestasi belajar mata kuliah statistika.

Analisis uji signifikansi peran kemampuan awal matematika dan persepsi mahasiswa pada mata kuliah statistika terhadap prestasi belajar mata kuliah statistika disajikan dalam tabel berikut.

Tabel 4. Analisis Uji Signifikansi Peran Kemampuan Awal Matematika dan Persepsi Mahasiswa pada Mata Kuliah Statistika terhadap Prestasi Belajar Mata Kuliah Statistika

\begin{tabular}{|c|c|c|c|c|c|c|}
\hline \multirow[t]{2}{*}{ Model } & & \multicolumn{2}{|c|}{$\begin{array}{l}\text { Unstandardized } \\
\text { Coefficients }\end{array}$} & \multicolumn{3}{|l|}{$\begin{array}{l}\text { Standardized } \\
\text { Coefficients }\end{array}$} \\
\hline & & B & Error & Beta & $\mathbf{t}$ & Sig. \\
\hline 1 & (Constant) & 28.117 & 8.216 & & 3.422 & 0.002 \\
\hline & Kemampuan_Awal_Matematika & 0.274 & 0.139 & 0.298 & 1.973 & 0.056 \\
\hline & Persepsi_Mahasiswa & 0.355 & 0.117 & 0.458 & 3.038 & 0.004 \\
\hline
\end{tabular}

Menguji hipotesis keberartian koefisien regresi parsial masing-masing sebagai berikut:

Menguji keberartian koefisien regresi $b_{1}$ :

Hipotesis yang di uji:

$$
\begin{aligned}
& \mathrm{H}_{0}: \beta_{1}=0 \\
& \mathrm{H}_{1}: \beta_{1} \neq 0
\end{aligned}
$$

Terlihat $t_{\text {hitung }}<t_{\text {tabel }}$ yaitu $1,973<2,021 \quad \mathrm{H}_{0}$ diterima $\mathrm{H}_{1}$ ditolak berarti tidak terdapat pengaruh positif dan signifikan antara kemampuan awal matematika terhadap prestasi belajar mata kuliah statistika.

Menguji keberartian koefisien regresi $b_{2}$ :

Hipotesis yag di uji:

$\mathrm{H}_{0}: \beta_{2}=0$

$\mathrm{H}_{1}: \beta_{2} \neq 0$

Terlihat $\mathrm{t}_{\text {hitung }}>\mathrm{t}_{\text {tabel }}$ yaitu 3,038>2,021 $\mathrm{H}_{0}$ ditolak $\mathrm{H}_{1}$ diterima berarti terdapat pengaruh positif dan signifikan antara persepsi mahasiswa pada mata kuliah statistika terhadap prestasi mata kuliah statistika. Persamaan regresi gandanya adalah $Y=28,117+0,274 \mathrm{X}_{1}+0,355 \mathrm{X}_{2}$ yang berarti bahwa kenaikan satu skor kemampuan awal matematika dan persepsi mahasiswa pada mata kuliah statistika akan memberikan kenaikan sebesar 0,274 untuk variabel $\mathrm{X}_{1}$ dan 0,355 untuk variabel $\mathrm{X}_{2}$ terhadap skor prestasi belajar mata kuliah statistika. 


\section{Pembahasan}

Pada pengolahan data kemampuan awal matematika terhadap prestasi belajar mata kuliah statistika memberikan hasil tidak signifikan, yang artinya tidak ada pengaruh positif yang berarti antara kemampuan awal matematika terhadap prestasi belajar mata kuliah statistika. Hal ini kembali menegaskan hasil penelitian sebelumnya, yaitu kemampuan awal tidak memberikan kontribusi berarti bagi variabel prestasi belajar mata kuliah statistika. Kemampuan awal adalah kemampuan yang telah dimiliki oleh peserta didik sebelum ia mengikuti pelajaran yang akan diberikan. Kemampuan awal menggambarkan kesiapan mahasiswa dalam menerima mata kuliah yang akan disampaikan. Kemampuan awal matematika mahasiswa perlu untuk diketahui dosen sebelum memulai pembelajaran karena dengan demikian dapat diketahui apakah mahasiswa tersebut telah mempunyai pengetahuan awal yang merupakan prasyarat untuk mengikuti pembelajaran. Hasil ini diartikan bahwa belum tentu semakin tinggi skor nilai kemampuan awal matematika mahasiswa akan semakin tinggi pula prestasi belajarnya, atau belum tentu semakin rendah kemampuan awal matematika mahasiswa maka akan semakin rendah pula prestasi belajarnya.

Pada pengolahan data persepsi mahasiswa terhadap prestasi belajar statistika memberikan hasil signifikan, yang artinya ada pengaruh positif yang berarti antara persepsi mahasiswa terhadap prestasi belajar mata kuliah statistika. Hal ini kembali menegaskan hasil penelitian sebelumnya, yaitu persepsi mahasiswa pada mata kuliah statistika memberikan kontribusi berarti bagi variabel prestasi belajar mata kuliah statistika. Persepsi mahasiswa pada mata kuliah statistika adalah suatu proses mahasiswa mengenali mata kuliah statistika. Ada mahasiswa yang mengenali dengan sikap positif yaitu menganggap mudah ada pula yang mengenali dengan sikap negatif yaitu menganggap sukar. Mahasiswa yang menyenangi mata kuliah statistik cenderung akan giat dan ikhlas mempelajari, sedangkan mahasiswa yang tidak menyenangi tentu saja akan malas-malasan untuk mempelajarinya. Hal tersebut tentu saja mempengaruhi prestasi belajar mata kuliah ststistika mahasiswa tersebut. Hasil ini diartikan bahwa semakin tinggi persepsi mahasiswa pada mata kuliah statistika maka akan semakin tinggi pula prestasi belajarnya, sebaliknya semakin rendah persepsi mahasiswa pada mata kuliah statistika maka akan semakin rendah pula prestasi belajarnya

Secara umum pengolahan keseluruhan data penelitian menunjukkan hasil yang signifikan yang artinya secara bersama-sama terdapat peran kemampuan awal matematika dan persepsi mahasiswa pada mata kuliah statistika terhadap prestasi belajar mata kuliah statistika. Fakta ini memberikan pemahaman baru bahwa kedua variabel ini secara sinergi dapat memunculkan performa terbaik mahasiswa, yaitu dengan mahasiswa dibekali kemampuan awal matematika yang baik dan mahasiswa diberikan pemahaman yang positif pada mata kuliah statistika akan mampu mendapatkan prestasi belajar yang baik pula.

\section{Simpulan dan Saran}

\section{Simpulan}

Berdasarkan hasil penelitian yang telah dilakukan dapat disimpulkan sebagai berikut: tidak terdapat pengaruh signifikan kemampuan awal matematika terhadap prestasi belajar mata kuliah statistika, terdapat pengaruh signifikan persepsi mahasiswa terhadap prestasi belajar mata kuliah statistika, serta kemampuan awal dan persepsi memberikan pengaruh secara bersama-sama terhadap prestasi belajar.

\section{Saran}

Penelitian ini masih dapat dikembangkan lebih luas, sehingga peneliti memberikan saran sebagai berikut: (1) Dosen diharapkan dapat memberikan motivasi kepada mahasiswa untuk lebih giat belajar latihan soal agar prestasi belajar meningkat, (2) Mahasiswa dengan persepsi yang tinggi diharapkan dapat memberikan motivasi kepada mahasiswa lain untuk mengikuti 
jejaknya, (3) Diadakan semacam mata kuliah umum atau pembekalan pada mahasiswa prodi TI mengenai mata kuliah yang akan ditempuh.

\section{Daftar Pustaka}

Adi, P. (2010). Pengaruh Metode Pembelajaran dan Persepsi Siswa pada Kompetensi Sosial Guru terhadap Kompetensi Belajar Matematika Siswa. Pascasarjana, Universitas Indraprasta PGRI Jakarta.

Astuti\&Leonard. (2012). Peran Kemampuan Komunikasi Matematika terhadap Prestasi Belajar Matematika Peserta Didik. Jurnal Formatif, Vol. 2 No. 2 Tahun 2012. 104105.

Chaplin, CP. (1999). Kamus Lengkap Psikologi. Edisi Indonesia. Jakarta: Raja Grafindo Persada.

Desmita. (2010). Psikologi Perkembangan Peserta Didik. Cetakan kedua. Bandung: PT Remaja Rosdakarya.

Liberna. (2009). Pengaruh Kebiasaan Belajar dan Kreativitas Siswa terhadap Hasil Belajar Matematika. Pascasarjana, Universitas Indraprasta PGRI Jakarta: hal 19.

Nirmalawati. (2010). Pengaruh Stres Belajar dan Motivasi Belajar terhadap Prestasi Belajar Matematika. Tesis. Jakarta: Universitas Indraprasta PGRI.

Slameto. (2010). Belajar dan Faktor-Faktor yang Mempengaruhinya. Jakarta: Rineka Cipta.

Supardi U.S. (2013). Aplikasi Statistika dalam Penelitian. Edisi Revisi. Jakarta: Prima Ufuk Semesta.

Suharnan. (2005). Psikologi Kognitif. Cet. 1. Surabaya: Penerbit Srikandi.

Sutrisno. (1993). Metodologi Research. Yogyakarta: Universitas Gajah Mada.

Trianto. (2007). Model-Model Pembelajaran Inovatif Berorientasi Konstruktivistik. Cet 1. Jakarta: Prestasi Pustaka. 